\title{
Optimization of Solid State Fermentation Conditions and Characterization of Thermostable Alpha Amylase from Bacillus subtilis (ATCC 6633)
}

Sujan Maity, Sanghamitra Mallik, Rwiti Basuthakur and Suvroma Gupta*

Department of Biotechnology, Haldia Institute of Technology, West Bengal, India

\begin{abstract}
Alpha amylase production using microbial source and solid state fermentation has been conducted for past few years in search of thermostable enzyme. Owing to the prolific use of thermostable alpha amylase in various industries like paper, food, detergent, brewing and starch liquefaction process, the production of alpha amylase is still going on. In the present work, Bacillus subtilis (ATCC 6633) has been utilized for generation of alpha amylase followed by optimization of the fermentation media. Change in fermentation conditions like fermentation hour, temperature, inoculums size, nitrogen and sugar sources have pivotal role to enhance alpha amylase yield. The thermal, $\mathrm{pH}$ and detergent stability of partially purified alpha amylase have been tested and compared with purified porcine pancreatic amylase. The result is encouraging with approximate $80 \%$ retention of alpha amylase activity comparable to purified porcine pancreatic amylase in presence of drastic condition of temperature $\left(60^{\circ} \mathrm{C}\right), \mathrm{pH}(6-11)$ and detergents. This makes it apt for use in various industries like detergent, food and paper industries.
\end{abstract}

Keywords: Fermentation; SSF; Thermostability; Activity; PPA

Abbreviations: WB: Wheat Bran; PPA: Porcine Pancreatic Amylase; SSF: Solid State Fermentation; DNS: Dinitrosalicylate; SDS: Sodium Dodecyl Sulphate; PB: Phosphate Buffer

\section{Introduction}

The ubiquitous starch splitting enzyme amylase [EC 3.2.1.1] has been a centre of research since decades. It splits starch liberating simple sugars like glucose, maltose and maltotriose [1]. Owing to its prolific use in industry, large scale production of amylase has been carried out using submerged and solid state fermentation with the help of microorganism like bacteria and fungi. However solid state fermentation is superior to submerged fermentation because of its number of additional advantages like simplicity, cost effectivity, easy availability, better productivity and lesser water output [2]. Wealth of information exists in support of wheat bran as the best sources among all the agro sources for extracellular amylase production for its higher starch content [3-6]. Bacillus species have been exploited by a number of researchers for the production of amylase using SSF [7-11]. They are growing increasingly important subject of study because of their thermostable enzyme productivity that has got myriad applications in number of industries. Bacillus species has become utilized due to their rapid growth rates giving rise to short fermentation cycles, known gene sequences, handling safety and capability to secrete extracellular enzymes in the fermentation media. Presently amylase encompasses considerable area of global enzyme market making starch liquefaction easier than former. In these respect members of the Bacillus family namely Bacillus licheniformis, Bacillus stearothermophilus etc. are being best utilized for thermostable alpha amylase production [12,13]. Thermostable amylase production would become an active area of research as it is being utilized in starch liquefaction, food, brewing, paper, pulp and detergent industry [14-17].

Keeping in mind the growing importance of alpha amylase, in the present work alpha amylase production has been optimized from Bacillus subtilis (ATCC 6633) using wheat bran as source of nutrient in SSF. Effect of fermentation hour, temperature, inoculum size, nitrogen and sugar source and extraction solvent have been tested for improved alpha amylase yield. Alpha amylase from fermented extract is characterized with a view point of $\mathrm{pH}$, thermal and detergent stability in order to evaluate it for the use in detergent industry $[18,19]$. The extracted partially purified amylase manifests moderate thermal and $\mathrm{pH}$ stability with an optimum activity at $60^{\circ} \mathrm{C}$ and at $\mathrm{pH}$ 7. It withstands alkaline $\mathrm{pH}$ with residual $81.39 \%$ of activity after three hours incubation at $\mathrm{pH} 11$ at $60^{\circ} \mathrm{C}$. Amylase preserves up to $50 \%$ of its initial activity even in presence of $5 \%$ SDS over three hours of incubation that qualifies it for the use of various industries.

\section{Materials and Methods}

\section{Organism used growth and solid state fermentation}

$25 \mathrm{ml}$ of nutrient broth is inoculated with a loop full of Bacillus subtilis (ATCC 6633) cells from a 24 hour old slant and kept at $37^{\circ} \mathrm{C}$ in a shaker. After 16-18 hours of growth, $1 \mathrm{ml}$ inoculum (around 1.5-2 $\times 10^{8}$ $\mathrm{cfu} / \mathrm{ml}$ ) from this broth culture has been added to the WB. Solid state fermentation has been carried out with $4 \mathrm{gm}$ dry wheat bran collected from local market in a $100 \mathrm{ml}$ Erlenmeyer flask. The moisture level of the wheat bran is kept at $50 \%(\mathrm{w} / \mathrm{w})$ with autoclaved distilled water. The contents of the flask are autoclaved prior to solid state fermentation [20].

Optimization of solid state fermentation parameters like fermentation hour, temperature and inoculum size for maximum amylase production

With handful of existing information regarding the inoculum size used for amylase production from SSF, the present study has been conducted with varying inoculums size from 2.5 to $20 \%$ (v/w).

*Corresponding author: Suvroma Gupta, Department of Biotechnology Haldia Institute of Technology, ICARE Complex, Purba Medinipur, 721657, WB India, Tel: 913-224-252-800; E-mail: suvg311@yahoo.co.in

Received February 26, 2015; Accepted March 27, 2015; Published March 31 2015

Citation: Maity S, Mallik S, Basuthakur R, Gupta S, et al.(2015) Optimization of Solid State Fermentation Conditions and Characterization of Thermostable Alpha Amylase from Bacillus subtilis (ATCC 6633). J Bioprocess Biotech 5: 218 doi: 10.4172/2155-9821.1000218

Copyright: (๑) 2015 Maity S, et al. This is an open-access article distributed under the terms of the Creative Commons Attribution License, which permits unrestricted use, distribution, and reproduction in any medium, provided the original author and source are credited. 
Citation: Maity S, Mallik S, Basuthakur R, Gupta S, et al.(2015) Optimization of Solid State Fermentation Conditions and Characterization of Thermostable Alpha Amylase from Bacillus subtilis (ATCC 6633). J Bioprocess Biotech 5: 218 doi: 10.4172/2155-9821.1000218

Page 2 of 7

With optimum inoculums size, SSF has been carried out for various fermentation periods (24, 48 and 72 hours) at different temperatures $\left(30^{\circ} \mathrm{C}, 40^{\circ} \mathrm{C}, 50^{\circ} \mathrm{C}\right.$ and $\left.60^{\circ} \mathrm{C}\right)$

\section{Amylase extraction after solid state fermentation}

Following fermentation the media comprising of wheat bran is mixed with $25 \mathrm{ml}$ of ice cold phosphate buffer $(20 \mathrm{mM}, \mathrm{pH}=7.0)$ for 30 minutes at $4^{\circ} \mathrm{C}$ in a rotary shaker at $150-200 \mathrm{rpm}$. The supernatant has been collected followed by centrifugation at $8000 \mathrm{rpm}$ for $15 \mathrm{~min}$ at $4^{\circ} \mathrm{C}$ and used for amylase assay. For optimization of appropriate extraction solvent, phosphate buffer $(20 \mathrm{mM}, \mathrm{pH}=7.0)$ has been substituted with phosphate buffer $(20 \mathrm{mM} \mathrm{pH}=7.0)$ that has incorporated $1 \%$ Triton-X 100 and Tween 20. After extraction the supernatant has been assayed for enzyme activity.

\section{Effect of supplements in wheat bran for optimum amylase production}

4 gram of wheat bran is supplemented with various inorganic nitrogenous salt $(0.125 \mathrm{M})$ like $\mathrm{NH}_{4} \mathrm{Cl},\left(\mathrm{NH}_{4}\right)_{2} \mathrm{SO}_{4}$ and $\mathrm{NH}_{4} \mathrm{NO}_{3}$ followed by incubation for 48 hours at $40^{\circ} \mathrm{C}$. The extraction of the enzyme is carried out following the same procedure as described earlier. Effect of organic nitrogen sources are also checked by addition of ( $1 \%$ by weight) peptone, tryptone and yeast extract in WB and extracted after 48 hours of fermentation as mentioned above. Simultaneously another set of fermentation experiments has been carried out in presence of sugars like glucose, starch and maltose (each with $1 \%$ by weight) in WB. The alpha amylase activity is determined according to DNS method [21].

\section{Amylase assay}

Alpha amylase activity of the extract is measured by DNS method [21]. In brief the reaction mixture containing $1 \%$ soluble starch, $20 \mathrm{mM}$ phosphate buffer $(\mathrm{pH}=7)$ and fermented extract is taken and incubates at $37^{\circ} \mathrm{C}$ for 20 minutes followed by the addition of 3,5-Dinitrosalicylic Acid (DNS). The amount of the reducing sugar liberated during assay is estimated by measuring color development at $540 \mathrm{~nm}$ by UV-VIS spectrophotometer (Hitachi). $1 \mathrm{U}$ of amylase activity is defined as the amount of enzyme that liberates 1 micromole of maltose per minute under standard assay condition. The experiments are carried out in triplicates and standard error is calculated.

\section{Protein estimation}

The protein content of the extract is determined following Lowry's method [22].

\section{Purification of amylase of Bacillus subtilis (ATCC 6633) from fermented extract}

Fermented extract has been subjected to ammonium sulfate precipitation at $30-80 \%$ saturation. The precipitate is collected by centrifugation at $12000 \times \mathrm{g}$ for $20 \mathrm{~min}$ at $4^{\circ} \mathrm{C}$. The precipitate is suspended in $20 \mathrm{mM}$ ice cold phosphate buffer ( $\mathrm{pH} 7)$ and dialyzed against the same buffer for 10 hours with three changes. The dialyzed solution is applied onto DEAE cellulose ion exchange chromatography pre equilibrated with the same $20 \mathrm{mM}$ phosphate buffer $(\mathrm{pH} 7)$. All the bound fractions with high $\mathrm{OD}_{280}$ have been collected after elution with $100 \mathrm{mM} \mathrm{NaCl}$. The flow through as well as elute have been estimated for protein content and amylase activity after desalting by dialysis. The entire procedure has been carried out at $4^{\circ} \mathrm{C}$.

\section{Effect of temperature on amylase activity}

The optimum temperature of the amylase is determined in 20 $\mathrm{mM}$ phosphate buffer $(\mathrm{pH}$ 7) over a range of temperature from 35$80^{\circ} \mathrm{C}$. Thermal stability of the partially purified amylase is tested after incubation of the purified enzyme in the same buffer at $60^{\circ} \mathrm{C}$ for 2 hours. In order to assess the thermal stability of purified amylase it has been compared with PPA incubated under identical experimental conditions. In both the cases, the residual amylase activity has been measured as described earlier.

\section{Sensitivity of amylase in various pHs and detergents}

The influence of $\mathrm{pH}$ and various detergents on the stability as well as activity of extracted amylase from Bacillus subtilis (ATCC 6633) has been checked to find its suitability in industry. Amylase activity has been measured in presence of buffers of different pHs using 20 $\mathrm{mM}$ citrate $(\mathrm{pH}=6.2)$, phosphate $(\mathrm{pH}=7.0)$, Tris- $\mathrm{HCl}(\mathrm{pH}=8.0)$ and Glycine- $\mathrm{NaOH}$ ( $\mathrm{pH}$ 9-11) by standard amylase assay. $\mathrm{pH}$ stability of the amylase has been estimated at $40^{\circ} \mathrm{C}$ after incubation of partially purified amylase for 0-3 hours in buffers of different $\mathrm{pHs}$ (6.2-11). The same assay procedure has been repeated accompanying incubation of extracted amylase in presence of detergents $(0-5 \%)$ namely Triton-X 100 , Tween 20 and SDS for a period of 1 hour at $60^{\circ} \mathrm{C}$.

\section{Statistical analysis}

Effect of each parameter was studied in triplicate and graphically represented as the mean $\pm S D(n=3)$ using Origin 5 .

\section{Results and Discussion}

\section{Effect of fermentation hours on amylase production during solid state fermentation}

With prior knowhow regarding the preferred use of WB among all agro wastes for improved alpha amylase production through SSF, the present work has been conducted with Bacillus subtilis ATCC 6633 and WB [2-5]. Success of SSF for enzyme production utilizing microbial resources largely depends on incubation period. The yield of alpha amylase from SSF varies with incubation period (24, 48 and 72 hours). The yield is maximum with $1160 \pm 9.4 \mathrm{U} / \mathrm{g}$ around 48 hours of fermentation. The alpha amylase activity declines on the both side at 24 hours and at 72 hours with activity $970 \pm 7.3 \mathrm{U} / \mathrm{g}$ and $1050 \pm 9.8 \mathrm{U} / \mathrm{g}$ respectively (Figure 1). The value can be correlated with the results of other workers supporting highest amylase production after 48 hours fermentation period [20]. Earlier study depicts that a clear correlation exists between bacterial growth and alpha amylase production [23]. The activity or production of amylase rises linearly with time up to 42 hours that merges with the sporulation pattern of Bacillus subtilis [23]. The fall in activity of amylase beyond 48 hours may be due to the denaturation or degradation of alpha amylase in presence of other components in the fermentation medium like protease etc. as noticed earlier [24].

\section{Effect of temperature and inoculum size on the production of amylase in solid state fermentation}

Temperature has profound effect on amylase yield as noticed from the result of SSF carried out at different temperatures for 48 hours. The activity of alpha amylase in the extracted media is highest at $40^{\circ} \mathrm{C}(1160 \pm 2.8 \mathrm{U} / \mathrm{g})$ that decays both at the higher and lower temperatures (Figure 2). Optimization of SSF for amylase production is largely dependent on inoculum size. Lower inoculum size implies 
Citation: Maity S, Mallik S, Basuthakur R, Gupta S, et al.(2015) Optimization of Solid State Fermentation Conditions and Characterization of Thermostable Alpha Amylase from Bacillus subtilis (ATCC 6633). J Bioprocess Biotech 5: 218 doi: 10.4172/2155-9821.1000218

Page 3 of 7

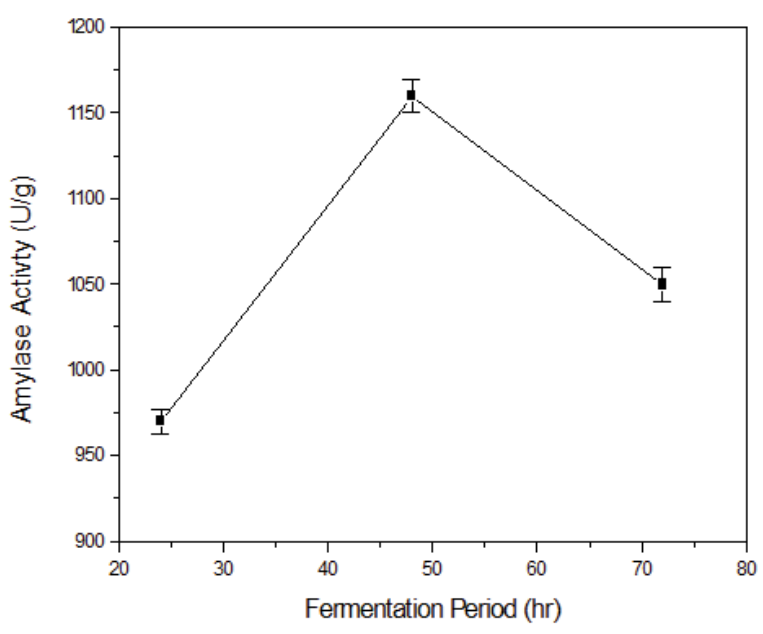

Figure 1: Optimization of fermentation hour for maximum amylase production by SSF from Bacillus subtilis (ATCC 6633).

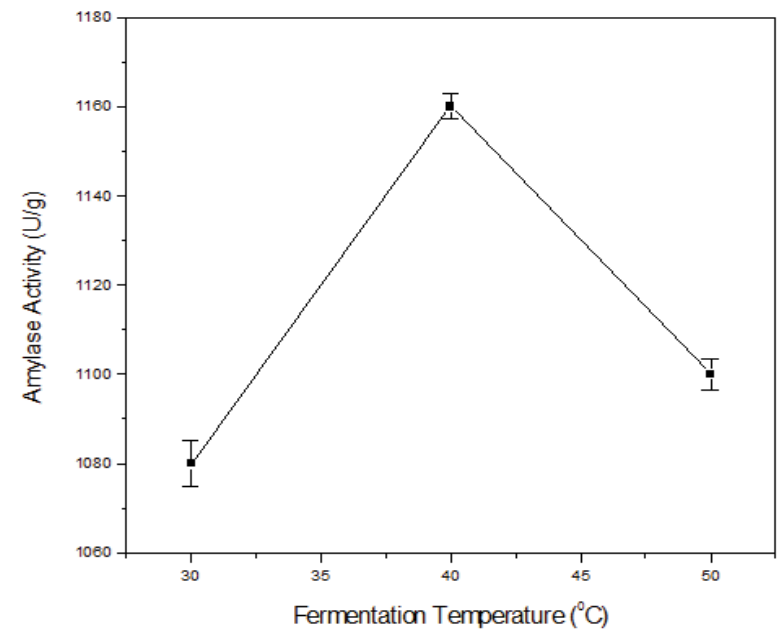

Figure 2: Optimization of fermentation temperature for maximum amylase production by SSF from Bacillus subtilis (ATCC 6633).

lesser number of cells in the production medium. This eventually increases fermentation time for enzyme synthesis as longer time is required to attain an optimum number of cells to utilize the substrate forming the desired product. Inoculum size regulates alpha amylase yield as observed from the variation of enzyme activity with change in inoculums' size (Figure 3). With $2.5 \%(\mathrm{~V} / \mathrm{W}$ ) inoculum, the activity in the fermented extract is $900 \pm 16.2 \mathrm{U} / \mathrm{g}$ increasing there by with the rise in inoculum size. The alpha amylase activity is highest when $10 \%$ inoculum has been used that is around $1150 \pm 6.7 \mathrm{U} / \mathrm{g}$. Decay in the amylase activity is evident thereafter with $20 \%$ inoculum $1020 \pm 9.6$ $\mathrm{U} / \mathrm{g}$. Comparison with earlier reports from Anto et al. is in agreement with the present result which shows that increase in inoculum size adversely affects the enzyme production [25]. Although work by Baysal et al. reports $20 \%$ inoculum size as optimum for SSF with wheat bran in amylase production [26]. However this may be an outcome of species variations that has been used for carrying out fermentation by different workers. However a likely explanation can be put forward in support of the above observation. Lower inoculum size accounts for less number of bacterial cells and lower nutrient consumption leading to the formation of less biomass that eventually manifests low amylase yield during SSF. However the productivity of amylase rises as inoculum size increases up to $10 \%$ due to optimum growth of Bacillus under specified medium environment with maximum available nutrient. With further hike in inoculum size, there is again a fall in alpha amylase activity at $20 \%$ inoculum size. It can be related with the inhibition of bacterial growth due to limiting nutrient supply in the fermentation media with concomitant poor amylase yield after 48 hours. Similar observation has also been reported by Gangadharan et al. [27].

\section{Effect of extraction solvent and nitrogen sources on the amylase yield from Bacillus subtilis (ATCC 6633):}

The nature of solvent used for extraction of crude enzyme may improve the yield of alpha amylase. Figure 4 shows highest activity of amylase when extracted with $20 \mathrm{mM}$ phosphate buffer $(\mathrm{pH} 7)$ compared to the solvents with nonionic detergent like Triton-X 100 and Tween 20 used for extraction (activity of amylase varies from 1030 to 1080 $\mathrm{U} / \mathrm{g}$ in presence of detergents in extraction solvent). This suppression in alpha amylase yield in presence of detergents like Triton-X 100 and Tween 20 can be attributed to the increased biomass formation. Similar observation regarding detergent effect on alpha amylase yield has also been mentioned by Benjamin et al. [28].

Presence of nitrogenous supplement in WB may improve the nutritional quality of WB that can influence amylase synthesis by producer microorganism. Alpha amylase yield has been augmented from solid state fermented production media with proper supplementation of $\mathrm{C}$ and $\mathrm{N}$ sources as they are absolutely necessary for microbial growth $[29,30]$. From earlier literature it is known that the presence of $\left(\mathrm{NH}_{4}\right)_{2} \mathrm{SO}_{4}, \mathrm{NH}_{4} \mathrm{Cl}$ and $\mathrm{NH}_{4} \mathrm{HPO}_{4}$ in SSF media along with $\mathrm{WB}$ stimulates enzyme production [31]. However in our studies, highest amylase yield has been observed in presence of $0.125 \mathrm{M}$ $\mathrm{NH}_{4} \mathrm{NO}_{3}(1410 \pm 16.9 \mathrm{U} / \mathrm{g})$ compared to the others (Figure 5). Organic nitrogen sources also modulates alpha amylase yield when present with WB in the SSF media. Among organic nitrogen sources 1\% tryptone is proved to be a better candidate $(1730 \pm 26.4 \mathrm{U} / \mathrm{g})$ followed by peptone $(1360 \pm 35.6 \mathrm{U} / \mathrm{g})$ when present in the SSF media. In contrary, yeast extract supplementation in WB is not promising enough in terms of alpha amylase activity $(880 \pm 13.2 \mathrm{U} / \mathrm{g})$. Earlier results also corroborates with our observation albeit a different school of thought exists [32,33]. Work done by Pandey et al. [17] reveals contradictory results indicating no differences in the amylase yield through SSF conducted in WB aided with different $\mathrm{N}$ sources [27]. According to them, WB apart from being a $\mathrm{C}$ source also serves as a source of $\mathrm{N}$ that abrogates the requirements of additional $\mathrm{N}$ sources in the fermentation media [34].

\section{Effect of sugar additives on the amylase yield from Bacillus subtilis (ATCC 6633) during solid state fermentation}

Being inducible enzyme, alpha amylase production is influenced by the presence of starch or its hydrolyzed product maltose in the fermentation media. Table 1 presents the activity of alpha amylase in presence of various C sources in SSF media along with WB. The amylase yield is highest in presence of maltose and soluble starch (1260 $\pm 8.2 \mathrm{U} / \mathrm{g}$ and $1230 \pm 24.6 \mathrm{U} / \mathrm{g}$ ) respectively compared to fermented WB $(1170 \pm 16.5 \mathrm{U} / \mathrm{g})$. This is in agreement with the observation reported in case of Bacillus thermoleovorans preferring starch, glucose, lactose, maltose and maltodextrin as carbon sources for amylase production [31]. Wealth of information is also available in this context regarding improved yield of amylase from Bacillus licheniformis, 
Citation: Maity S, Mallik S, Basuthakur R, Gupta S, et al.(2015) Optimization of Solid State Fermentation Conditions and Characterization of Thermostable Alpha Amylase from Bacillus subtilis (ATCC 6633). J Bioprocess Biotech 5: 218 doi: 10.4172/2155-9821.1000218

Page 4 of 7

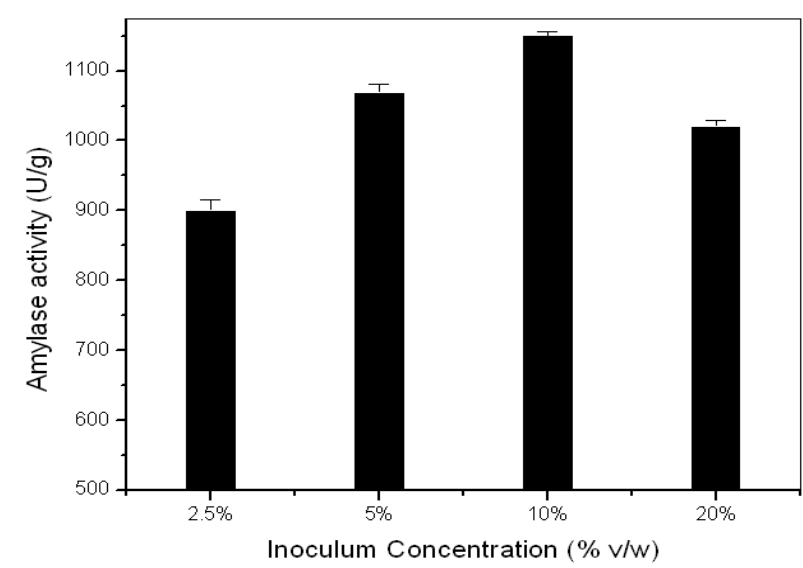

Figure 3: Effect of inoculum concentration on amylase activity from fermented extract.

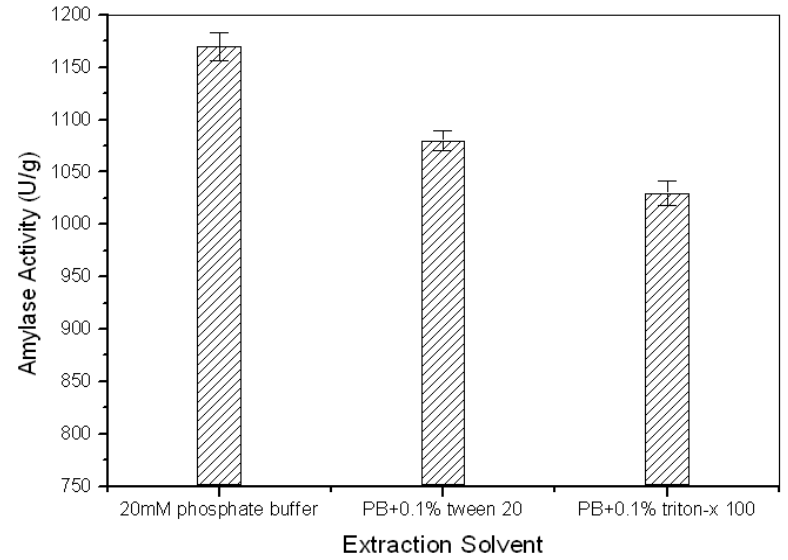

Figure 4: Effect of extraction solvent on amylase production after 48 hour SSF using $B$. subtilis (ATCC 6633)

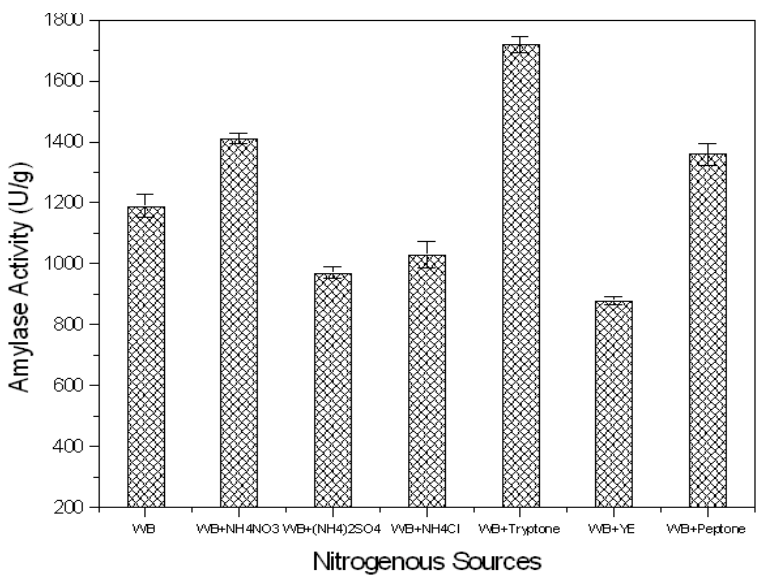

Figure 5: Effect of nitrogen sources $(0.125 \mathrm{M}$ for inorganic salts and $1 \%$ for organic nitrogenous sources) on amylase yield from SSF using Bacillus subtilis (ATCC 6633).
Bacillus species I 3 and Bacillus Stearothermophilus in presence of starch in the fermentation media [10,34]. However in the present study, glucose in wheat bran represses alpha amylase yield $(1110 \pm 14.3 \mathrm{U} / \mathrm{g}$ compared to $1170 \pm 16.5 \mathrm{U} / \mathrm{g}$ ) because of its rapid uptake by bacteria in preference to other complex sugars like maltose, dextrin etc. due to catabolite repression. This promotes better bacterial growth reducing the necessity of alpha amylase production. This is in agreement with the observation of Pandey et al. with similar trend of decrease in alpha amylase yield in the presence of glucose compared to WB alone [17,27].

\section{Optimum $\mathrm{pH}$ and temperature of amylase}

Earlier reports depict a temperature range with optimum alpha amylase activity oscillating from $40^{\circ} \mathrm{C}$ for an alkalophilic Bacillus species to $95^{\circ} \mathrm{C}$ for amylase from Bacillus subtilis and Bacillus amyloliquefaciens [35]. However majority of alpha amylase have their optimum activity of $\mathrm{pH} 7.0$ at approximate $65^{\circ} \mathrm{C}$ [36-38]. From literature review it is known that alkalophilic amylase is mostly thermolabile [18]. On the other hand acidophilic alpha amylase is thermostable [34]. It is crucial to determine the optimum $\mathrm{pH}$ for amylase as it is related to the use of enzyme in various sectors of industry. Alpha amylase extracted from SSF has optimum activity at pH $7.0(1230 \pm 21.23 \mathrm{U} / \mathrm{g})$. In the present case alpha amylase is showing maximum activity around $60^{\circ} \mathrm{C}$ $(1650 \pm 9.81 \mathrm{U} / \mathrm{g})$ with $50 \%$ decline in activity $(800 \pm 9.23 \mathrm{U} / \mathrm{g})$ at $80^{\circ} \mathrm{C}$ (Figure 6a and Figure 6b).

\section{Purification of amylase of Bacillus subtilis (ATCC 6633) from solid state fermented extract}

Amylase from the fermented extract has been purified after ammonium sulphate fractionation at $30-80 \%$ saturation. The activity and specific activity of amylase in the fermented extract is $1160(\mathrm{U} / \mathrm{ml})$ and $446(\mathrm{U} / \mathrm{mg})$ respectively. Table 2 presents the gradual purification of amylase as observed from the improvement of specific activity values of the amylase in comparison with the amylase from fermented extract. For the estimation of the structure and molecular weight of amylase, the SDS-PAGE analysis has been conducted (Figure 7). SDS gel electrophoresis analysis manifests the presence of a single band near $66 \mathrm{kDa}$. This molecular weight matches with the previous reports (54 to $68 \mathrm{kDa}$ ) regarding the molecular weight of purified amylase from other sources [39].

\section{Estimation of thermal stability of amylase}

During thermal stability the activity of purified amylase has been compared with the activity of PPA incubated under identical conditions. The amylase activity estimated under 0 hour of incubation has been considered as $100 \%$ for both the purified as well as for PPA. Activity of the incubated amylases at various hours has been calculated as the residual activity and plotted against period of incubation. In the present case, purified alpha amylase from Bacillus subtilis keeps back approximate $80 \%$ activity upon incubation for 2 hour at $60^{\circ} \mathrm{C}$. Its thermal stability has been compared with purified PPA incubated under identical condition that retains $87 \%$ of the activity (Figure 8). Thermal stability of alpha amylase has been disseminated from the constituent amino acids as revealed from work by Suzuki et al. [13]. They identified a region (Gln 178) and region II (255 to 270 residues) of Bacillus licheniformis amylase to be essential for imparting thermostability [13]. Deamidation of Asn/Gln residue for Bacillus licheniformis has been evolved as a cause of thermal inactivation. However extra thermal stability has been induced due to additional salt bridge formation among lys 385, lys 88 and /or lys 253 [12]. Amylases 
Citation: Maity S, Mallik S, Basuthakur R, Gupta S, et al.(2015) Optimization of Solid State Fermentation Conditions and Characterization of Thermostable Alpha Amylase from Bacillus subtilis (ATCC 6633). J Bioprocess Biotech 5: 218 doi: 10.4172/2155-9821.1000218

\begin{tabular}{|c|c|}
\hline Inducer & Enzyme Activity (U/g) \\
\hline WB & $1170 \pm 16.5$ \\
\hline WB + Glucose $(0.01 \mathrm{gm})$ & $1110 \pm 14.3$ \\
\hline WB + Maltose $(0.01 \mathrm{gm})$ & $1260 \pm 8.2$ \\
\hline WB + Starch $(0.01 \mathrm{gm})$ & $1230 \pm 24.6$ \\
\hline
\end{tabular}

Table 1: Effect of sugars on amylase yield from SSF.

\begin{tabular}{|c|c|c|c|c|}
\hline Sample & Activity (U/ml) & $\begin{array}{c}\text { Protein } \\
\text { content (mg/ } \\
\mathbf{m l})\end{array}$ & $\begin{array}{c}\text { Specific } \\
\text { activity } \\
\mathbf{( U / m g )}\end{array}$ & $\begin{array}{c}\text { Purification } \\
\text { fold }\end{array}$ \\
\hline $\begin{array}{c}\text { Crude fermented } \\
\text { Extract }\end{array}$ & 1160 & 2.6 & 446 & 1 \\
\hline $30-80 \%$ & 6820 & 4.1 & 1664 & 3.7 \\
\hline $\begin{array}{c}\left(\mathrm{NH}_{4}\right)_{2} \mathrm{SO}_{4} \text { saturation } \\
\begin{array}{c}\text { DEAE cellulose } \\
\text { chromatography (Flow } \\
\text { through) }\end{array}\end{array}$ & 4259 & 1.6 & 2662 & 6 \\
\hline
\end{tabular}

Table 2: Partial Purification of amylase from Bacillus subtilis (ATCC 6633) fermented extract

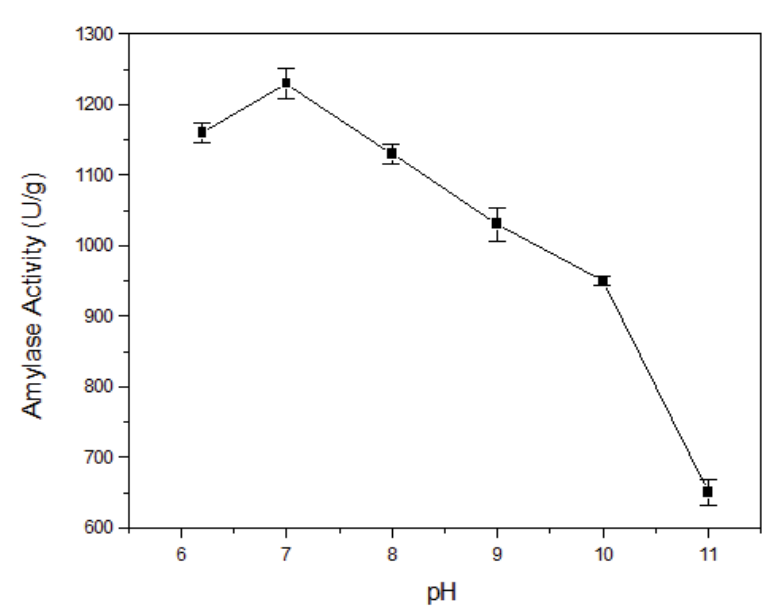

Figure 6a: Optimum pH of $\alpha$ amylase from SSF extract using $B$. subtilis (ATCC 6633).

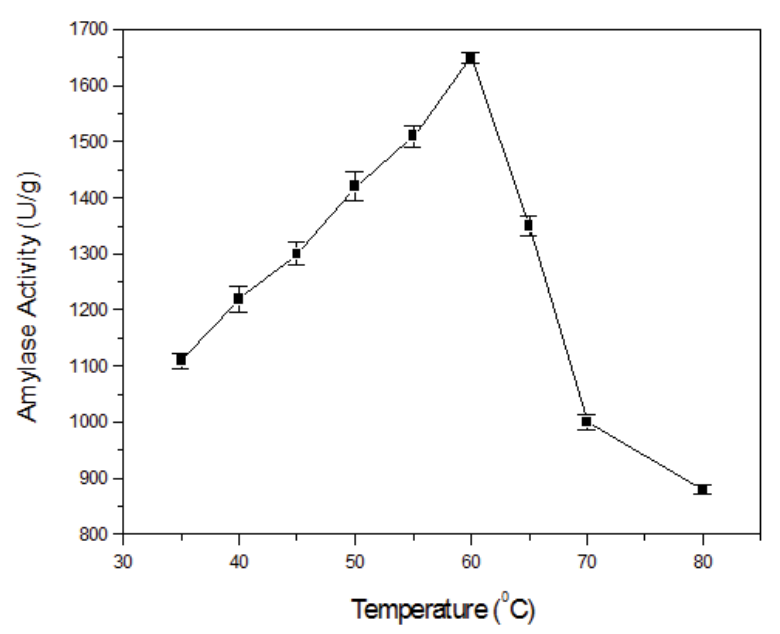

Figure 6b: Optimum temperatures of $\alpha$-amylase from SSF extract using $B$. subtilis (ATCC 6633).

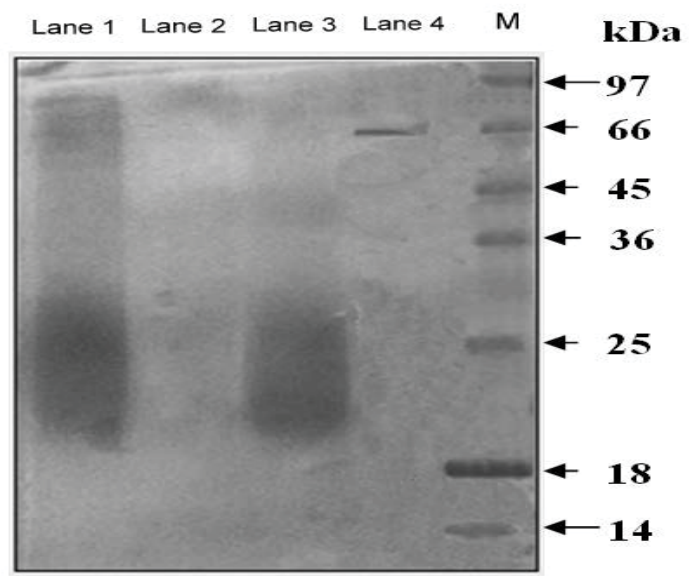

Figure 7: $12 \%$ SDS PAGE of 48 hour fermented extract of $B$. subtilis (ATCC 6633) Lane 1, 48 hours fermented extract $(4 \mu \mathrm{g})$, Lane 2, 0-30\% fraction of ammonium sulphate precipitated fermented extract, lane $3,30-80 \%$ fraction of ammonium sulphate precipitated fermented extract, Lane 4, Purified amylase, Lane M, Standard molecular weight markers (Sigma).

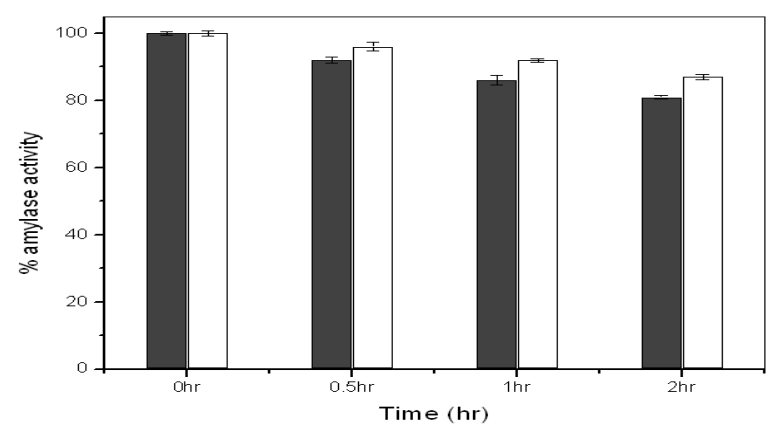

Figure 8: Thermal stability of alpha amylase $(\square)$ and its comparison with PPA $(\square)$.

vary in their thermostability as evident from the series from Bacillus licheniformis CUMC305 to Bacillus stearothermophilus. In the former the maximum activity of amylase is retained at $\mathrm{pH} 9.0$ with $91 \%$ residual activity at $100^{\circ} \mathrm{C}[40]$. Owing to the thermal stability at $60^{\circ} \mathrm{C}$ this alpha amylase from Bacillus subtilis is able to preserve its activity against thermal inactivation. Thermostable alpha-amylases are used for starch liquefaction process at high temperature whereas thermolabile amylases are used for the saccharification of starch in baking. This can be an effective addition to industries for long lasting stability and activity.

\section{pH and detergent stability of amylase}

Owing to the rising demands of amylase in detergent industry, it is essential to check the stability of amylase in presence of detergents. In addition it is worthwhile to determine the $\mathrm{pH}$ stability of alpha amylase. Amylase stability has been derived from the estimation of amylase activity at varying conditions of buffer $\mathrm{pH}$ and detergents. Activity of amylase has been presented as \% of residual activity as stated before. Amylase is able to retain about around $80 \%$ of its activity after 3 hours of incubation at $40^{\circ} \mathrm{C}$. This trend is maintained even at $\mathrm{pH} 11$ 
Citation: Maity S, Mallik S, Basuthakur R, Gupta S, et al.(2015) Optimization of Solid State Fermentation Conditions and Characterization of Thermostable Alpha Amylase from Bacillus subtilis (ATCC 6633). J Bioprocess Biotech 5: 218 doi: 10.4172/2155-9821.1000218

Page 6 of 7

although in the acidic $\mathrm{pH}$ zone, the loss in alpha amylase activity is more pronounced (Figure 9). When incubated in the presence of $1 \%$ SDS the amylase activity is preserved up to an extent of $77 \%$ albeit it decreases thereafter in the presence $5 \%$ SDS (with $52 \%$ remaining activity) at $60^{\circ} \mathrm{C}$ after 1 hour. Nonionic detergents like (0.1\%) Tween-20 or Triton X 100 also stabilizes alpha amylase. In presence of $5 \%$ Tween-20, the activity of alpha amylase increases from $1400 \mathrm{U} / \mathrm{g}$ to $1624 \mathrm{U} / \mathrm{g}$. Triton $\mathrm{X} 100$ also offers protection and protects alpha amylase activity as manifested from (Table 3). Compared to the purified PPA, subjected under similar experimental conditions, alpha amylase of Bacillus subtilis (ATCC 6633) has retained its activity up to a significant extent in presence of various detergents. This substantiates its direct use in a number of industries.

\section{Conclusion}

Alpha amylase produced after solid state fermentation from Bacillus subtilis (ATCC 6633) appears to have potential in industries due to its thermal, $\mathrm{pH}$ and detergent stability. Further studies are to be continued with the goal of performing its production in pilot scale. Data originated from this study will help to design experimental set up for large scale production of amylase. Evaluation of other biochemical and biophysical parameters like sensitivity towards ions, inhibitors, reaction kinetics and structural studies are to be performed to validate its use in industries. Divalent cations like calcium and magnesium ions increase the thermal stability of amylase so it will be relevant to check the effects of these ions in the fermentation media for the improvement

\begin{tabular}{|c|c|c|c|c|c|c|}
\hline \multirow[b]{2}{*}{$\begin{array}{c}\text { Concentration of } \\
\text { detergents }(\%)\end{array}$} & \multicolumn{2}{|c|}{ SDS } & \multicolumn{2}{|c|}{ Tween 20} & \multicolumn{2}{|c|}{ Triton X 100} \\
\hline & $\begin{array}{l}\text { Amylase activity } \\
\qquad(\mathrm{U} / \mathrm{g}) \\
\text { from fermented } \\
\text { extract }\end{array}$ & $\begin{array}{c}\text { Amylase activity } \\
\text { (U/g) } \\
\text { (PPA) }\end{array}$ & $\begin{array}{l}\text { Amylase activity } \\
\qquad(\mathrm{U} / \mathrm{g}) \\
\text { from fermented } \\
\text { extract }\end{array}$ & $\begin{array}{c}\text { Amylase activity } \\
\text { (U/g) } \\
\text { (PPA) }\end{array}$ & $\begin{array}{l}\text { Amylase activity } \\
\text { (U/g) } \\
\text { from fermented } \\
\text { extract }\end{array}$ & $\begin{array}{c}\text { Amylase activity } \\
\text { (U/g) } \\
\text { (PPA) }\end{array}$ \\
\hline 0 & $1140 \pm 17.5$ & $1390 \pm 9.82$ & $1150 \pm 11.3$ & $1400 \pm 8.62$ & $1150 \pm 7.29$ & $1400 \pm 9.64$ \\
\hline 1 & $878 \pm 6.37$ & $1126 \pm 12.4$ & $1173 \pm 8.73$ & $1442 \pm 5.46$ & $1311 \pm 11.5$ & $1638 \pm 13.9$ \\
\hline 3 & $730 \pm 9.89$ & $1036 \pm 14.3$ & $1208 \pm 4.27$ & $1512 \pm 12.2$ & $1414 \pm 13.8$ & $1764 \pm 7.51$ \\
\hline 5 & $593 \pm 10.48$ & $897 \pm 7.84$ & $1277 \pm 9.57$ & $1624 \pm 9.17$ & $1495 \pm 5.38$ & $1918 \pm 8.32$ \\
\hline
\end{tabular}

Table 3: Effect of detergents on alpha amylase activity.

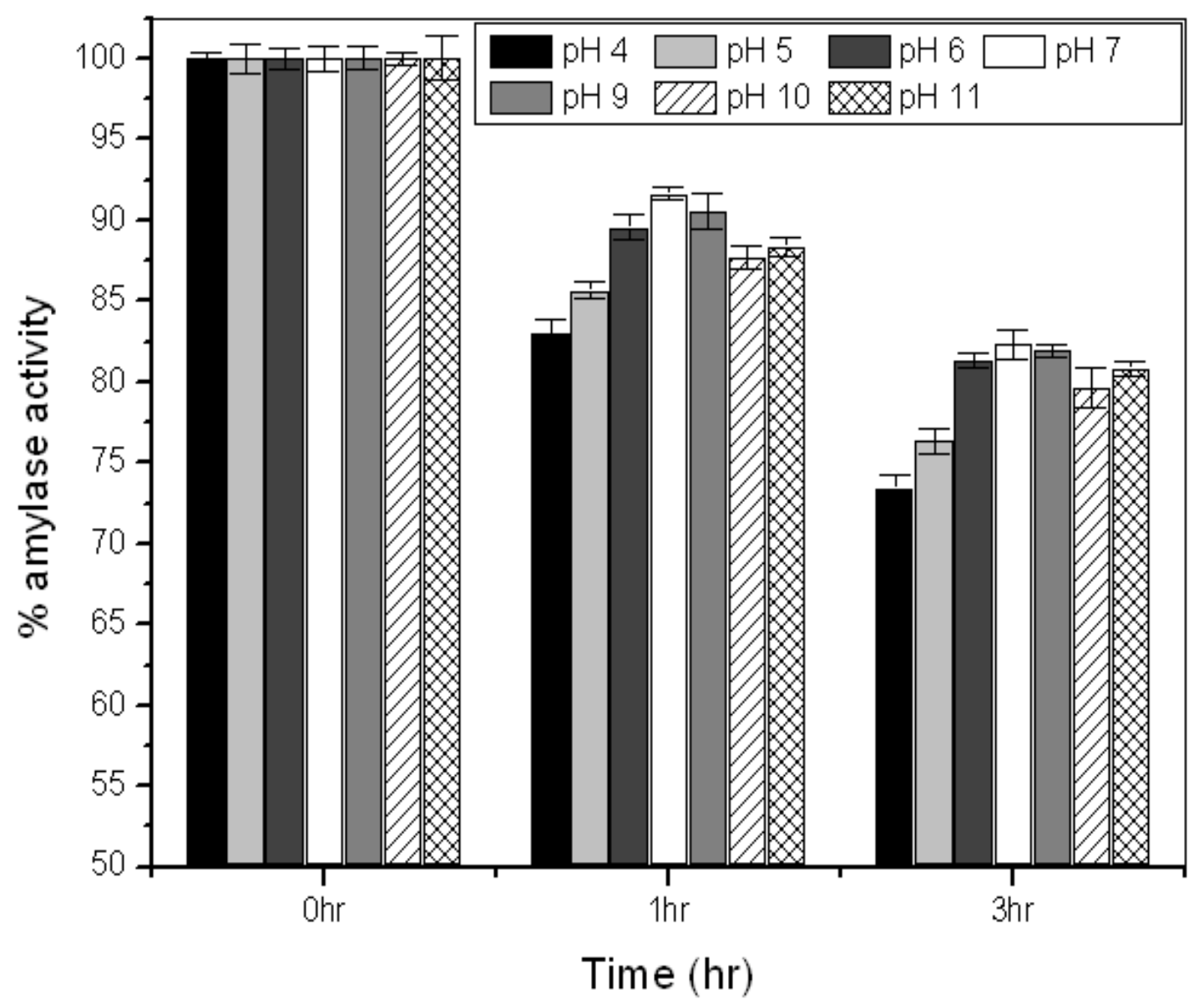

Figure 9: $\mathrm{pH}$ stability of alpha amylase. 
Citation: Maity S, Mallik S, Basuthakur R, Gupta S, et al.(2015) Optimization of Solid State Fermentation Conditions and Characterization of Thermostable Alpha Amylase from Bacillus subtilis (ATCC 6633). J Bioprocess Biotech 5: 218 doi: 10.4172/2155-9821.1000218

of thermal stability of amylase. This may pave the pathway to justify its commercial utility.

\section{Acknowledgement}

The authors are thankful to the Department of Biotechnology, Haldia Institute of Technology for infrastructural support.

\section{References}

1. Rameshkumar A, Sivasudha T (2011) Optimization of nutritional constitute for enhanced $\alpha$-amylase production by solid state fermentation technology. Int $J$ Microbiol Res 2: 143-148

2. Kandra $L$ (2003) $\alpha$-Amylases of medical and industrial importance. J Mol Struct (Theochem) 666-667: 487-498.

3. Mulimani VH, Patil Ramalingam GN (2000) a-Amylase production by solid state fermentation: a new practical approach to biotechnology courses. Biochem Educ 28: 161-163.

4. Ikram-ul-Haq, Ashraf H, lqbal J, Qadeer MA (2003) Production of alpha amylase by Bacillus licheniformis using an economical medium. Bioresour Technol 87: 57-61.

5. Shukla J, Kar R (2006) Potato peel as a solid state substrate for thermostable a-amylase production by thermophilic Bacillus isolates. World $\mathrm{J}$ Microbiol Biotechnol 22: 417-422.

6. Vijayabaskar P, Jayalakshmi D, Shankar T (2012) Amylase production by moderately halophilic Bacillus cereus in solid state fermentation. Afr J Microb Res 6: 4918-4926.

7. Saxena RK, Dutt K, Agarwal L, Nayyar P (2007) A highly thermostable and alkaline amylase from a Bacillus sp. PN5. Bioresour Technol 98: 260-265.

8. Asgher M, Asad MJ, Rahman SU, Legge RL (2007) A thermostable a-amylase from a moderately thermophilic Bacillus subtilis strains for starch processing. J Food Eng 79: 950-955.

9. Hamilton LM, Kelly CT, Fogarty WM (1999) Production and properties of the raw starch-digesting $\alpha$ - amylase of Bacillus sp. IMD 435. Process Biochem 35: 27-31.

10. Goyal N, Gupta JK, Soni SK (2005) A novel raw starch digesting thermostable a-amylase from Bacillus sp. I-3 and its use in the direct hydrolysis of raw potato starch. Enzyme Microbiol Technol 37: 723-734

11. Schwab K, Bader J, Brokamp C, Popovic MK, Bajpai R, et al. (2009) Dual feeding strategy for the production of alpha-amylase by Bacillus caldolyticus using complex media. N Biotechnol 26: 68-74.

12. Tomazic SJ, Klibanov AM (1988) Why is one Bacillus alpha-amylase more resistant against irreversible thermoinactivation than another? J Biol Chem 263: 3092-3096.

13. Suzuki Y, Ito N, Yuuki T, Yamagata H, Udaka S (1989) Amino acid residues stabilizing a Bacillus alpha-amylase against irreversible thermoinactivation. J Biol Chem 264: 18933-18938.

14. Ito S, Kobayashi T, Hatada Y, Horikoshi K (2005) Enzymes in modern detergents. Methods Biotechnol 17: 151-161

15. Reddy NS, Nimmagadda A, Rao KRSS (2003) An overview of the microbial a amylase family. Afr J Biotechnol 2: 645-648

16. Gupta R, Gigras P, Mohapatra H, Goswami VK, Chauhan B (2003) Microbial a-amylases: a biotechnological perspective. Process Biochem 38: 1599-1616.

17. Pandey A, Nigam P, Soccol CR, Soccol VT, Singh D, et al. (2000) Advances in microbial amylases. Biotechnol Appl Biochem 31 : 135-152.

18. Bernhardsdotter ECMJ, Ng JD, Garriott OK, Pusey ML (2005) Enzymic properties of an alkaline chelator-resistant $\alpha$-amylase from an alkaliphilic Bacillus sp. isolate L1711. Process Biochem 40: 2401-2408.

19. Lee S, Oneda H, Minoda M, Tanaka A, Inouye K (2006) Comparison of starch hydrolysis activity and thermal stability of two Bacillus licheniformis alphaamylases and insights into engineering alpha-amylase variants active under acidic conditions. J Biochem 139: 997-1005.

20. Raul D, Biswas T, Mukhopadhyay S, Kumar Das S, Gupta S (2014) Production and Partial Purification of Alpha Amylase from Bacillus subtilis (MTCC 121) Using Solid State Fermentation. Biochem Res Int 2014: 568141.
21. Miller GL (1959) Use of dinitrosalisylic acid reagent for determination of reducing sugar. Chem 31: 426-429.

22. Lowry OH, Rosebrough NJ, Farr AL, Randall RJ (1951) Protein measurement with the Folin phenol reagent. J Biol Chem 193: 265-275.

23. Mukhtar H, Ikram-Ul-Haq (2012) Concomitant production of two proteases and alpha-amylase by a novel strain of Bacillus subtilis in a microprocessor controlled bioreactor. Braz J Microbiol 43: 1072-1079.

24. Lonsane BK, Ghildyal NP, Budiatman S, Ramakrishna SV (1985) Engineering aspects of solid state fermentation. Enzyme Microb Technol 7: 258-265.

25. Anto H, Trivedi U, Patel K (2006) Alpha Amylase Production by Bacillus cereus MTCC 1305 Using Solid-State Fermentation. Food Technol. Biotechnol 44: 241-245.

26. Baysal Z, Uyar F, Aytekin C (2003) Solid-state fermentation for production of $\alpha$-amylase by a thermotolerant Bacillus subtilis from hot-spring water. Process Biochem 38: 1665-1668

27. Gangadharan D, Sivaramakrishnan S, Nampoothiri KM, Pandey A (2006) Solid Culturing of Bacillus amyloliquefaciens for Alpha Amylase Production. Food Technol Biotechnol 44: 269-274.

28. Benjamin S, Smitha RB, Jisha VN, Pradeep S, Sajith S, et al. (2013) A monograph on amylases from Bacillus spp. Adv Biosci Biotechnol 4: 227-241.

29. Pedersen H, Nielsen $J(2000)$ The influence of nitrogen sources on the alpha-amylase productivity of Aspergillus oryzae in continuous cultures. Appl Microbiol Biotechnol 53: 278-281.

30. el-Akher MA, el-Leithy MA, el-Marsafy MK, Kassim SA (1973) Optimal conditions for production of bacterial amylase. Zentralbl Bakteriol Parasitenkd Infektionskr Hyg 128: 483-490.

31. Narang S, Satyanarayana T (2001) Thermostable alpha-amylase production by an extreme thermophile Bacillus thermooleovorans. Lett Appl Microbiol 32 : 31-35.

32. Chandra AK, Medda S, Bhadra AK (1980) Production of extracellular thermostable $\alpha$-amylase by Bacillus licheniformis. J Ferment Technol 58: 1-10.

33. Babu KR, Satyanarayana T (1995) a-Amylase production by thermophilic Bacillus coagulans in solid state fermentation. Process Biochem 30: 305-309.

34. Ikram-ul-Haq, Ashraf H, Iqbal J, Qadeer MA (2003) Production of alpha amylase by Bacillus licheniformis using an economical medium. Bioresour Technol 87: 57-61.

35. El-Tayeb O, Mohammad F, Hashem A, Aboul-wafa M (2008) Optimization of the industrial production of bacterial alpha amylase in Egypt. IV. fermentor production and characterization of the enzyme of two strains of Bacillus subtilis and Bacillus amyloliquefaciens. Afr J Biotechnol 7: 4521-4536.

36. Arikan B1 (2008) Highly thermostable, thermophilic, alkaline, SDS and chelator resistant amylase from a thermophilic Bacillus sp. isolate A3-15. Bioresour Technol 99: 3071-3076.

37. Nagarajan DR, Rajagopalan G, Krishnan C (2006) Purification and characterization of a maltooligosaccharide-forming alpha-amylase from a new Bacillus subtilis KCC103. Appl Microbiol Biotechnol 73: 591-597.

38. Sodhi HK, Sharma K, Gupta JK, Soni SK (2005) Production of a thermostable a-amylase from Bacillus sp. PS-7 by solid state fermentation and its synergistic use in the hydrolysis of malt starch for alcohol production. Process Biochem 40: $525-534$

39. Ueda M, Asano T, Nakazawa M, Miyatake K, Inouye K (2008) Purification and characterization of novel raw-starch-digesting and cold-adapted alphaamylases from Eisenia foetida. Comp Biochem Physiol B Biochem Mol Biol 150: $125-130$

40. Krishnan T, Chandra AK (1983) Purification and Characterization of alphaAmylase from Bacillus licheniformis CUMC305. Appl Environ Microbiol 46: 430-437. 